\title{
Institutional Problems in Regional Public Services
}

\author{
Asna Aneta ${ }^{1}$, Yanti Aneta ${ }^{1}$, Hais Dama ${ }^{2}$ \\ ${ }^{1} 1$ Department of Administrative Science, Universitas Negeri Gorontalo \\ 2 Department of Management, Universitas Negeri Gorontalo \\ Email: asnaatiek.aneta@ung.ac.id
}

(Diterima: 11-Oktober-2018; di revisi: 13-November-2018; dipublikasikan: 30-Desember-2018)

\begin{abstract}
The objective of this descriptive qualitative research is to explore and to analyze the institutional problems in regional public services. It employed direct observation and interview focusing on the issues of the regional public service institutions. This study was conducted at One-stop Administration system (henceforth called Samsat) in Gorontalo City. The results show that the implementation of the services is carried out according to the standard operation of the services, ranging from the procedures, work duration, service products, and innovation. Nevertheless, the problems surrounding the institution are inevitable. The issues revolve around a) the system and organization of the implementation, b) limited qualified human resources, c) lack of facilities and infrastructures, as well as d) the service strategy.
\end{abstract}

Key Words: Institutional Problem, Public Service, One-stop Administration Office Gorontalo.

\begin{abstract}
ABSTRAK
Tujuan dari penelitian kualitatif deskriptif ini adalah untuk mengeksplorasi dan menganalisis masalah kelembagaan dalam pelayanan publik regional. Penelitian ini melakukan pengamatan langsung dan wawancara yang berfokus pada isu-isu lembaga pelayanan publik regional. Penelitian ini dilakukan di Kantor Administrasi One-stop (selanjutnya disebut Samsat) di Kota Gorontalo. Hasil penelitian menunjukkan bahwa implementasi layanan dilakukan sesuai dengan standar operasi layanan, mulai dari prosedur, durasi kerja, produk layanan, dan inovasi. Namun demikian, masalah di sekitar lembaga tidak bisa dihindari. Persoalannya berkisar pada a) sistem dan organisasi pelaksanaan, b) sumber daya manusia yang berkualitas terbatas, c) kurangnya fasilitas dan infrastruktur, serta d) strategi layanan.
\end{abstract}

Kata Kunci: Masalah Kelembagaan, Layanan Publik, Kantor Administrasi Satu Pintu Gorontalo

Copyright (C) 2018 Universitas Negeri Makassar. This is an open access article under the CC BY license (http://creativecommons.org/licenses/by/4.0/)

Number: (RISTEKDIKTI) 21/E/KPT/2018 


\author{
80 Jurnal Ilmiah Ilmu Administrasi Publik: Jurnal Pemikiran dan Penelitian Administrasi Publik \\ Volume 8 Nomor 2 Juli - Desember 2018. Hal 79-86
}

\title{
INTRODUCTION
}

A government plays a significant role in providing quality public services to the society (Janita \& Miranda, 2018; Sá, Rocha, \& Pérez Cota, 2016; Sharma \& Mishra, 2017; Wirtz, Weyerer, \& Schichtel, 2018)(Nilwana, Akib, Rusdi, \& Tahmir, 2015; Sunusi, Makmur, Tawe, $\&$ Tahir, 2014). This notion has been constituted in the Act Number 25 of 2009 considering the Public Services Article 1. This regulation defines public service as an activity or series of procedures in the context of fulfilling needs in accordance with the laws and regulations for every citizen and population of goods, services and administrative services provided by public service providers. The regulation signifies the task of the public services is to ensure its work quality to serve the community (Akib \& Ihsan, 2017; Batley \& Mcloughlin, 2015; Caloghirou, Protogerou, \& Panagiotopoulos, 2016; Kunda, Akib, Tahmir, Malik, \& Arifin, 2015; Ocampo et al., 2017; Van Gobel, Akib, Tahmir, \& Made, 2015).

A report by USAID-Local Governance Support Program, henceforth called LGSP in short, shows that problems, such as the improvement of data management, an organization of the service and the relation with the user persist in the efforts to the rejuvenation of public service in the Regency and city government. LGSP encourages the reform-oriented local government work unit in regencies and cities to implement varying mechanisms of public services and its accountability as well as to collaborate with related stakeholders (Story, 2009).

It is revealed that the mentoring program by LGSP in several provinces yields a significant outcome as shown in Deli Serdang regency, Sumatera Utara. The public services in this area decide to implement a superior program in five among 32 public clinics. Another success story of LGSP is an integrated service center of sub-district office of Pinrang regency, South Sulawesi. LGSP assist the office to cope with the problem in organizing and recruiting human resources and to provide guidance on administrative services. In Sragen and Jembrana regency, LGSP has successfully reformed and establish the standard of one-way public services through information, technology and communication system as the back office of the government bureaucracy in Jembrana, Bali (Syukri, 2009).

In the recent reformation age, public services are urged to reform the decentralized institutional system and management as well as to improve the quality of human resources according to the conceptualization of good governance. This concept is manifested through the attitude of state apparatus in carrying out their duties and enhance their performance in providing public services to all people regardless of their status. If the government is unable to provide free services to the public, the cost of the services should be minimized as not all people are able to afford it (Story, 2009).

One-way system or an integrated system is among the attempt by the government in the sector of public service. This system has been implemented by the regional government, i.e. the integrated public system in sub-district office and one-stop administration office (henceforth called Samsat). Samsat is an integration of several services by polices, regional revenue services, and Jasa Raharja insurances. Such integration helps the society to access the administration of their vehicles.

The services by this one-roof service are registration of the vehicle, vehicle tax, transfer of motor vehicle ownership, payment of compulsory traffic accident funds, and road transport 
donations in an integrated and coordinated manner in the Joint Office of one-roof service. The one-way administrative system office of Gorontalo City distributes the tasks and authority of the regional tax revenue to optimize the Local own-source revenue, including a) vehicle tax administration by regional financial department (Badan Keuangan Daerah or BKD), b) the receipt of retribution by criminal investigation of regional police office (reskrim polda), c) the payment of Compulsory Contribution to Traffic Accident Insurance Fund by Jasa Raharja insurance (SWDKLLJ).

These three institutions are integrated into one site to enhance the efficiency, i.e., maximizing professional, quality services and promoting accountability. This is reflected by embodying values, such as accountability, responsibility, transparency, effectiveness, and efficiency within the services by the office to the community as the user.

Poor implementation of the services to the user is the focus of the government to provide quality public services. Attempts, such as establishing the standard of services, creating innovation, the capacity of service standard enhancement to speed up the service, promoting accurate, affordable and transparent service have been made by the government. However, it is yet to attain effective result in the society as the user. In reality, the problems of the public service institution are determined on three aspects, namely: 1) the pattern or system of implementation; 2) human resource support (competence/professional); 3) supporting infrastructure and 4) service strategy. These have implications for the quality of less professional services.

Professional state administration or bureaucracy is essential to build public-oriented services. The professionalism of the officers that resonates to the good governance principle is equality, i.e., providing the same treatment in the services; equity, i.e., prioritizing equal treatment for the community; loyalty, i.e., showing loyalty to the constitution, law, leader, subordinates and co-workers; and accountability. The value of accountability refers to the behavior that every government apparatus must be prepared to the responsibilities and preventing the paradigm of "I just do the assigned task" Mertin Jr (Loh, Coyte, \& Cheng, 2018).

In the light of the above context, this research discovers the issues that hinder the implementation of public service offices. Several approaches that have been attempted are a rejuvenation in sectors, such as system and strategy of services, facilities, and infrastructures (including technology innovation), capacity enhancement (development of human resources), and developing the performance of institution as the public service provider in committing to create a better change.

\section{METHOD}

This case study employed a qualitative approach and was conducted in a one-stop administration office in Gorontalo City. The data were generated from the main informants of the research, i.e., the user of the service and the employees of the office. They were selected purposively. The sample was selected using snowball sampling; this step was done until the data were sufficiently gathered. Furthermore, the research instrument comprises: a) observation guideline, b) interview, c) questionnaire, d) focus group discussion material, e) forms to generate the secondary data, and f) document relevant to this study. The data were collected 


\author{
82 Jurnal Ilmiah Ilmu Administrasi Publik: Jurnal Pemikiran dan Penelitian Administrasi Publik \\ Volume 8 Nomor 2 Juli - Desember 2018. Hal 79-86
}

from focused observation, in-depth interview, conducting focus group discussion, and identification of the document. This data analysis activity was carried out interactively and continuously until through several systematic steps. These steps include collecting data records, data reduction, data presentation, verification and summing up the conclusion.

\title{
RESULT AND DISCUSSION
}

The public service offices in Gorontalo Province are urged to enhance the efficiency, i.e., maximizing professional, quality services and promoting accountability. This is reflected by values embodies, e.g., accountability, responsibility, transparency, effectiveness, and efficiency within the services by the office to the community as the user. The rapid growth of society demands the government's contribution to provide quality public services. This is the responsibility of institutions as civil servants who are urged to be more professional in providing quality services.

\section{The One-stop Administration Office}

The One-stop Administration Office of Gorontalo City has attempted to standardize its services, including a) the procedures of the administrative process, b) duration, c) service products, d) expenses, and e) facilities and infrastructures; Procedures of Administrative Services. A clear guideline of the procedures of the administrative process should be adhered by the user. It is revealed that some people do not follow the step of the administrative processes. This can be addressed by providing media, such as a) web pages, b) infographic, c) leaflet, d) conducting workshops and disseminating the idea through the electronic platform to inform the people. Collaborating with the government and transportation companies also helps people to access the information regarding tax vehicle and avoiding the involvement of middleman. 2). Duration. The completion time has been determined according to the rules and type of vehicle/taxpayer compliance with varying duration; this applies to the administrative processes for vehicle licenses. However, some people complain that it takes too long to get the licenses. This is because there are many administrative processes that should be done by which it results in a long queuing. One of the solutions is to integrate the recent online technology that allows the people to do every administrative process anytime and everywhere. This resonates to the attempt by the government in Sragen and Jembrana regency. The government has successfully reformed and establish the standard of one-way public services through information, technology and communication system as the back office of the government bureaucracy in Jembrana, Bali (Syukri:2010). 3). Services Offered. Services offered by the One-stop administration office are issuing vehicle registration certificate, vehicle registration number plate, and certificate of vehicle ownership. Regional Finance and Asset Office is Payment Proof of Vehicle Tax (Local Government Agency/Notice tax), Payment Proof of Transfer of Vehicle Title Fee (Local Government Agency/No); c) PT Jasa Raharja (limited liability company) is Fund Card Sticker of Compulsory Contribution to Traffic Accident Insurance Fund, those are the master service products at One-stop Administration Office of Gorontalo City. Besides, innovations made in improving public services are Drive-Thru service, Mobile One-stop Administration Office, and 
Door to Door Service. These innovative products have been prepared in the form of a separate place and room so that costumers do not need to queue and can even take a very short time. It is expected that the customers have also prepared predetermined requirements, such as Identity Card, Vehicle Ownership Certificate, and Vehicle Registration Certificate. However, this facility has not yet been carried out because some people argue that Vehicle Ownership Certificate is still used for collateral, the car's ownership has changed from the first-hand owner to the second-hand owner, tax arrears, and other matters. This situation indicates that the socialization performed on Drive-Thru service, Mobile One-stop Administration Office and Door to Door service has not been optimal. This is very regrettable if people do not use these provided services that will reduce the queue. 4). Service Charge. Every service given to the community should have a certain charge so that it will not cause a problem. Based on the secondary data, all types of services have a definite charge created in a standing banner in order to facilitate the users to read the information, help people finish their business without going through a middleman. 5). Facilities and Infrastructure. Facilities and infrastructure are requirements needed by service users and providers according to service activities in the form of primary and supporting facilities. The results of the interview reveal that One-stop Administration Office of Gorontalo City still lacks facilities and infrastructure. This needs the addition of facilities, particularly service counter, an internet network, waiting room, and the like. This needs to be anticipated by having cooperation with the third party by using an online system to facilitate costumers paying the tax and other administrations.

Based on the above description, the implementation design of One-stop Administration Office of Gorontalo City is identical to the figure of the service gap that has been previously shown, which is the gap between the taxpayer and the service provider. This is due to the lack of information through research, interactive discussion, or Focus Group Discussion (FGD) to collect information from various parties, including employees as service providers and the users to improve the system. Further, the classical factor that should be reformed is that too many bureaucratic levels in the service unit.

\section{Resources Support}

The existing resources are the significant support for quality services. Human resources are the vital factor in supporting the process of performance in an organization. For this reason, professional and reliable human resources are required as an effort to maximize services. In addition, skilled human resources must have a strong perspective and humanitarian side, for example, empathy as the main factor of resources as a service agency. The competence and professionalism improvement in doing their activities as a public service provider can be obtained through education and training activities, technical guidance, and other training. The competence of service providers both from the knowledge, skills, and attitude needs to be developed through training. Training is conducted to acquire more insights, skills, and attitude in order that they understand their primary duty as service providers. Moreover, employees' responsiveness will indicate the dimension of the most dynamic service quality, so that the users will be satisfied and convinced that every service performed is in accordance with the speed, accuracy, easiness, efficiency, and quality of services provided (Parasuraman, 2001:69).

The results of the interview show that people have suggested that service counter should have more personnel. Besides, the competence is still limited that they need to participate in a 


\section{$84 \mid$ Jurnal Ilmiah Ilmu Administrasi Publik: Jurnal Pemikiran dan Penelitian Administrasi Publik Volume 8 Nomor 2 Juli - Desember 2018. Hal 79-86}

training or technical guidance, especially about how to serve the taxpayer. Financial and advanced technological support in the field of ICT in particular along with the physical appearance such a feasible building can influence the image of a strong commitment of the government in providing quality services to the community.

\section{Institution}

From the institutional side, the main weakness in the organization design that is not specifically designed in terms of giving services to the community is full of hierarchy that can create a bureaucratic service and is not coordinated. The tendency to perform regulation and implementation functions at the same time is still often carried out by the government that also causes public services becoming inefficient (Syukri: 2009).

Several problems of public services management provided by the government are identified below:

1. Weaknesses come from the difficulty to determine or to measure the output or quality of services provided by the government.

2. Services given by the government have high uncertainty so that the relation between the output and input cannot be clearly determined.

3. The government's services in improving public services quality in regions can be applied through a strong moral commitment of the regional apparatus (Regional Revenue Office of Gorontalo Province, Regional Police or in this case the Traffic Director, Jasa Raharja, and stakeholders' support. A strong commitment to leadership, especially the Regional Heads, supported by the internal team or staff can significantly optimize the quality improvement of public services in their region. The internal team of the regional government is positioned as a reformer in the bureaucratic system. This team consists of the Head of Office or the officials that have the same vision, mission, and strategy as the Regional Head. In addition to the internal team of the regional government, the involvement of other stakeholders (external team) is also necessary to give a helpful suggestion, evaluation, and recommendation for the quality improvement of public services.

\section{CONCLUSION}

Problems in public services in a region include a system/design of implementation that has not been optimal, limited human resources support, limited facilities and infrastructure that is impactful on the service innovation, optimal planning of public services. The changes of organization form and regional government's governance as the results of the central government's policy indirectly influence the quality of services in a region. 


\section{REFERENCES}

Akib, H., \& Ihsan, A. (2017). Bureaucratic Reform in Public Service: A Case Study on the One Stop-Integrated Service. Mediterranean Journal of Social Sciences, 8(2), 253.

Batley, R., \& Mcloughlin, C. (2015). The Politics of Public Services: A Service Characteristics Approach. World Development, 74, 275-285. https://doi.org/https://doi.org/10.1016/j.worlddev.2015.05.018

Caloghirou, Y., Protogerou, A., \& Panagiotopoulos, P. (2016). Public procurement for innovation: A novel eGovernment services scheme in Greek local authorities. Technological Forecasting and Social Change, 103, 1-10. https://doi.org/https://doi.org/10.1016/j.techfore.2015.10.016

Janita, M. S., \& Miranda, F. J. (2018). Quality in e-Government services: A proposal of dimensions from the perspective of public sector employees. Telematics and Informatics, 35(2), 457-469. https://doi.org/https://doi.org/10.1016/j.tele.2018.01.004

Kunda, A., Akib, H., Tahmir, S., Malik, T., \& Arifin, R. (2015). Measure The Level Of Satisfaction Level And Attitude Of Service Recipients Of Public Service Sector. International Journal of Academic Research, 7.

Loh, C.-Y., Coyte, R., \& Cheng, M. M. (2018). Is a fresh pair of eyes always better? The effect of consultant type and assigned task purpose on communicating project escalation concerns. Management Accounting

Research. https://doi.org/https://doi.org/10.1016/j.mar.2018.09.002

Nilwana, A., Akib, H., Rusdi, M., \& Tahmir, S. (2015). Competency-Based Analysis On Government Apparatus'performance In Sidenreng Rappang Regency South Sulawesi Province. International Journal of Academic Research, 7(1).

Ocampo, L., Alinsub, J., Casul, R. A., Enquig, G., Luar, M., Panuncillon, N., ... Ocampo, C. O. (2017). Public service quality evaluation with SERVQUAL and AHP-TOPSIS: A case of Philippine government agencies. Socio-Economic Planning Sciences. https://doi.org/https://doi.org/10.1016/j.seps.2017.12.002

Sá, F., Rocha, Á., \& Pérez Cota, M. (2016). From the quality of traditional services to the quality of local e-Government online services: A literature review. Government Information Quarterly, 33(1), 149-160. https://doi.org/https://doi.org/10.1016/j.giq.2015.07.004

Sharma, R., \& Mishra, R. (2017). Investigating the role of intermediaries in adoption of public access outlets for delivery of e-Government services in developing countries: An empirical study. Government Information Quarterly, 34(4), 658-679. https://doi.org/https://doi.org/10.1016/j.giq.2017.10.001

Story, R.-L. (2009). Large Group Scenario Planning. The Change Handbook: The Definitive Resource on Today's Best Methods for Engaging Whole Systems: Easyread Large Bold 
86 | Jurnal Ilmiah Ilmu Administrasi Publik: Jurnal Pemikiran dan Penelitian Administrasi Publik Volume 8 Nomor 2 Juli - Desember 2018. Hal 79-86

Edition, 199.

Sunusi, S., Makmur, M., Tawe, A., \& Tahir, H. (2014). The Implications Of The Development Strategy Of Local Government Officials Resources. International Journal Of Academic Research, 6(5), 39-43.

Syukri, A. F. (2009). Standar pelayanan publik pemda berdasarkan ISO 9001/IWA-4. Kreasi Wacana.

Van Gobel, L., Akib, H., Tahmir, S., \& Made, A. (2015). Innovation Of Public Service In Meeting The Basic Needs In Gorontalo, Indonesia. International Journal of Academic Research, 7(1).

Wirtz, B. W., Weyerer, J. C., \& Schichtel, F. T. (2018). An integrative public IoT framework for smart government. Government Information Quarterly. https://doi.org/https://doi.org/10.1016/j.giq.2018.07.001 